\title{
Quinquereme of Nineveh
}

\author{
The perils of long-haul travel.
}

\section{Chaz Brenchley}

Birds carry seeds, merchants carry word of other lives. Civilizations rise on trade, exchange, cargoes: it's all about the traffic.

As a little boy I loved to go for a family hike up the mountain, but what was best in the day came early and late, going up and coming down. Our path crossed a motorway as we left the city; and what I would anticipate beforehand and remember after was standing with my hands clenched around the railings of the bridge, gazing down, seeing cars and trucks and coaches hurtle beneath me, this way and that. Uncounted strangers, unimaginable lives: all their individual errands and needs and urges dragging them into this common rush, this sense of progress. Traffic.

I could have stood and watched them go for ever.

Apparently, I still can.

This particular night I should have been one among them, man in car, one pixel in the glow. It would have made far better sense. But no: I had to be a boy again this night, this one night, this world of waiting.

I was lucky, I suppose, that I could walk to work. Every time it felt like walking into the future: from what had been my parents' house, through my childhood - with a pause, a ritual pause on the footbridge, look down at the road, watch the traffic and then up and over the mountain.

The bridge at night was more of a teenage memory, a cluster of us kicking our legs above the traffic, staying out as late as we dared, passing cigarettes and cans up and down the line and talking, talking. And always looking down.

Kids still do that. I passed a bunch of them rail-hugging like my own private ghosts and wanted to stop, wanted to say look up, look up! - but we never did, they never would and there was nothing to see yet in any case, against the light-stain of the city's glow.

Besides, they were no ghosts of mine. Their future was on a different track. Tonight more than ever I felt like a dead end, an evolutionary sideshow.

Pass them by, then, and never mind the whispers, the giggles at my back. I'd have giggled too.

Up the winding path, difficult in the dark but my feet remembered; and found it less steep than they recalled, that sudden

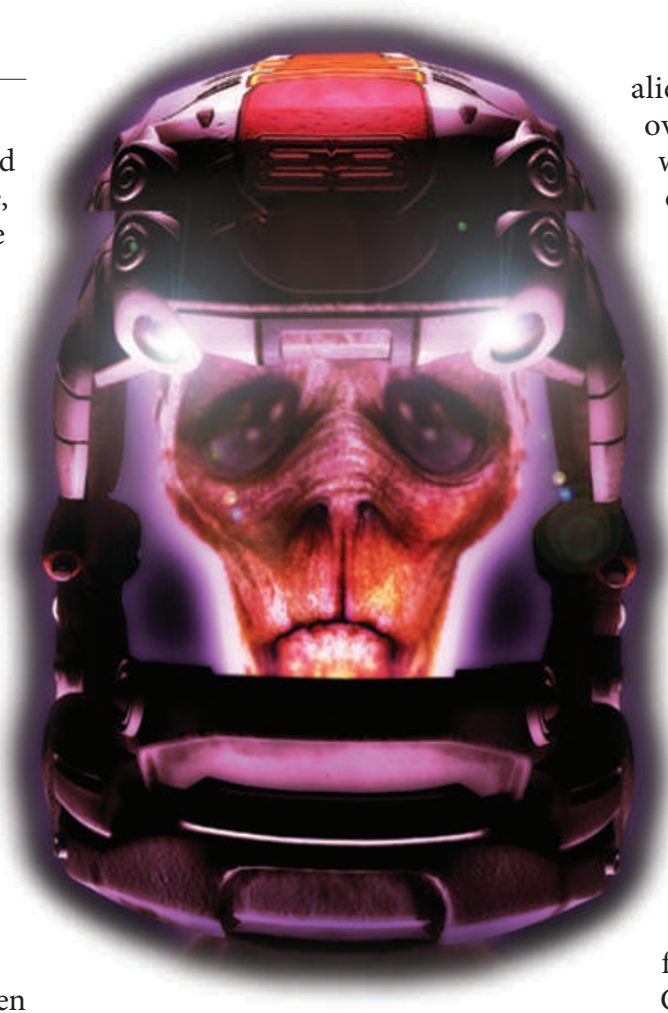

shock of adulthood still lingering even in middle-age. You think you've made adjustments, fitted the world to your new scale, and you're still wrong.

There should have been crowds on the peak, whispers and hush, a lingering anticipation.

Two men there were, with a single boy between them. Telescopes and cameras, they had the works, and the amateur enthusiasm to go with them: but still. I thought the night deserved better.

I bade them a soft good evening and went on by.

On the other side of the mountain, all the broad sweep of the airfield lay below me: more lights, a lure, duty calls. Truly, though, all my work now was waiting, and I could do it just as well up here.

No telescope, no camera, but I had brought my binoculars, and I did know just where to look. There was old reliable Orion, there was his belt and the sword on his belt; and there, what was that, a smudge on the scabbard, a new jewel, an adornment ...?

Even then, I barely needed the binoculars. After an hour, they were swinging disregarded from my neck while I just looked. Not a new star, no. Not a supernova. Not a comet, not an asteroid inbound, nobody's calamity.

Traffic.

I stood there and watched it all the way in. By the time it was clearly a ship, a starship, alien and unique, there were people all over the mountainside at last, rowdy with alcohol or trainspotter-fussy about detail, where I thought they should all be hushed with respect.

Too much to ask. When the Sun came up and I went down, I was picking my way through a litter of discarded cans and burger-wraps, thinking it should have been champagne and oysters. You owed them that at least.

I should have been fighting my way through a scrum of press and public, and I wasn't. That was the worst of it, almost, that almost nobody cared.

Almost the worst.

When everything had cooled enough, the ship's door finally cracked open and alien figures came stalking down a ramp. For them this was a great event, a culmination, the pursuit of many lifetimes; and waiting for them, what they found was me.

Greeting them impossibly in their own tongue.

Knowing their ancestries in detail, the long course of generations from their home star to ours.

"We are not the first?" they said, bereft. "We thought we were the first..."

"You were ... overtaken." By information, by the speed of light: messages that could be translated, understood. Machines that could be built. Instantaneous transfer, across a terrible span.

Traffic.

What need ships, when we could send people, news, tech and luxuries across the Galaxy at the touch of a button?

Isolated in their unreachable vessel, they didn't know and couldn't be told. On and on they had sailed, already redundant, their histories known and their trade goods long superseded.

People massed on the scorched tarmac at my back, and the newcomers tried to draw comfort from that. "These, who are they in their eagerness, in their want?"

"Oh," I said. "Those? Those are archaeologists."

Chaz Brenchley has been a professional writer since he was 18 , working mostly in crime, horror, fantasy and science fiction. He claims to live down the dirty end of genre fiction. In fact, he lives in Newcastle on Tyne.

Join the discussion of Futures in Nature at go.nature.com/QMAm2a 